https://doi.org/10.52058/2786-4952-2021-4(4)-201-213

Кравцов Віталій Олександрович кандидат педагогічних наук, доцент, доцент кафедри педагогіки спеціальної та соціальної освіти, Центральноукраїнський державний педагогічний університет імені Володимира Винниченка, вул. Шевченка, 1, м. Кропивницький, 25006, тел.: (095) 717-96-82, e-mail: Vit_Kravtsov@ukr.net, https://orcid.org/0000-0003-4824-2036

\title{
АКМЕОЛОГІЧНИЙ ПІДХІД У ФОРМУВАННІ МЕТОДОЛОГІЧНОЇ КУЛЬТУРИ СОЦАЛЬНОГО ПРАЦІВНИКА
}

Анотація. У статті висвітлено теоретичні засади формування методологічної культури соціального працівника. На основі аналізу базових категорій «методологія» і «культура» обгрунтовано авторське розуміння сутності й змісту методологічної культури як важливої професійної характеристики соціального працівника.

Методологічну культуру соціального працівника визначено як цілісне багаторівневе i багатокомпонентне утворення у структурі особистості, що містить знання фахової методології, володіння методами і методологією наукового пізнання, розумову діяльність в режимі методологічної рефлексії, розвинуті здібності критичного аналізу професійної діяльності, систему інтеріоризованих педагогічних та загальнолюдських цінностей, котрі визначають професійну свідомість.

Обгрунтовано, що важливою характеристикою методологічної культури соціального працівника $є$ готовність і спрямованість до самовдосконалення, досягнення акме у професійній діяльності, що забезпечує розвиток професійних якостей і характеристик шляхом адекватної, методологічно обгрунтованої самооцінки $\mathrm{i}$ оперативного усунення виявлених у процесі діяльності особистісних недоліків, вдосконалення рівня професіоналізму відповідно до вимог часу, досягнення вершин у професійному розвиткові.

Визначено сутнісні та змістовні зв'язки між процесами професіоналізації та формування методологічної культури соціального працівника. Професіоналізм соціального працівника досліджено в контексті акмеологічного підходу, як бажаний результат та вершину професійного розвитку особистості. Методологічна культура інтерпретується як одна 3 важливих характеристик та критеріїв професіоналізму соціального працівника. Визначено змістовні характеристики методологічної культури. Окреслено зміст методологічної компетентності та ціннісно-мотиваційної сфери соціального працівника.

Показано взаємозв'язки запровадження акмеологічного підходу з іншими теоретичними підходами у формуванні методологічної культури соціального 
Журнал«Герспектвиитаіноовації наукиљ

(Серія«Гедагогіка», Серія«Гцихологія», Серія«Медицинв»

№4(4) 2021

працівника: антропологічним, діяльнісний, системним, аксіологічним, культурологічним.

В контексті акмеологічного підходу визначено соціально-педагогічні умови формування методологічної культури майбутнього соціального працівника. Обгрунтовано, що реалізація акмеологічного підходу у професійній підготовці майбутніх соціальних працівників є важливою запорукою забезпечення якості та ефективності цього процесу.

Ключові слова: методологічна культура, методологія, культура, акмеологія, професіоналізм.

Kravtsov Vitaliy Oleksandrovych Candidate of Pedagogical Sciences, Associate Professor, Associate Professor of the Department of Pedagogy of Special and Social Education, Volodymyr Vynnychenko Central Ukrainian State Pedagogical University, Shevchenka St., 1, Kropyvnytskyi, 25006, tel.: (095) 717-96-82, e-mail: Vit_Kravtsov@ukr.net, https://orcid.org/0000-0003-4824-2036

\section{ACMEOLOGICAL APPROACH IN THE FORMATION OF METHODOLOGICAL CULTURE OF A SOCIAL WORKER}

Abstract. The article determines the theoretical principles of the methodological culture of a social worker formation. Based on the analysis of the basic categories "methodology" and "culture", the author's comprehension of the essentiality and content of methodological culture as an important professional characteristic of a social worker is substantiated.

Methodological culture of a social worker is defined as an integral multilevel and multicomponent formation in the structure of personality. It contains knowledge of professional methodology, mastery of methods and methodology of scientific knowledge, mental activity in the methodological reflection mode, developed abilities of critical analysis of the professional activity, system of introduction of pedagogical and universal values that determine professional consciousness.

It is grounded that an important characteristic of the methodological culture of a social worker is the preparedness and focus on self-improvement, achieving acme in professional activities. This ensures the development of professional qualities and characteristics through adequate, methodologically sound self-assessment and prompt removing of identified personal imperfections in the process, improving the level of professionalism in accordance with the requirements of the time, reaching the top in professional development.

The essential and meaningful connections between the processes of professionalization and formation of the methodological culture of a social worker are determined. The professionalism of a social worker is studied in the context of the acmeological approach as a desired result and the acme of professional development of the individual. Methodological culture is interpreted as one of the important 
characteristics and criteria of social worker professionalism. The meaningful characteristics of methodological culture are determined. The content of methodological competence and value-motivational sphere of a social worker is defined.

The interrelations of the introduction of the acmeological approach with other theoretical approaches in the formation of the methodological culture of the social worker are disclosed: anthropological, activity, system-defined, axiological and cultural.

In the context of the acmeological approach, the socio-pedagogical conditions for the formation of the methodological culture of the future social worker are determined. It is proved that the implementation of the acmeological approach in the future social workers training is an important pledge of success of quality and efficiency of this process.

Keywords: methodological culture, methodology, culture, acmeology, professionalism.

Постановка проблеми. У стандарті вищої освіти зі спеціальності 231 «Соціальна робота» передбачено формування у майбутнього соціального працівника широкого кола соціальних, фахових та загальнокультурних компетентностей, що зумовлює реалізацію у процесі професійної підготовки сукупності теоретичних підходів: системного, діяльнісного, аксіологічного, акмеологічного, культурологічного тощо.

Дослідження О.Анісімова, С.Бондаревської, А.Маркової, В.Сластеніна та ін. показують, що якісно високий рівень професіоналізму досягається фахівцями у процесі довготривалої професійної діяльності та самовдосконалення. Проте, вже молодий соціальний працівник, який тільки розпочинає трудову діяльність, має володіти не тільки знаннями, вміннями і навичками, що складають основу його професійної компетентності, але й методологією професійної діяльності, інструментарієм i спрямованістю до творчої діяльності, якостями i характеристиками, що обумовлюють подальший професійний розвиток i успішність професійної діяльності. Тому останнім часом активізувалися дослідження методологічної культури, яку окремі дослідники (О.Бережнова, Є.Бондаревська, Г.Валєєв, В.Краєвський, О.Ходусов та ін.) розглядають як важливу особистісно-професійну характеристику, що з одного боку характеризує його професіоналізм, 3 іншого - $\epsilon$ інтегруючим утворенням у професійній структурі особистості, що спрямовує особистісний і культурний розвиток у сфері професії. Отже, дослідження теоретичних та методичних засад формування методологічної культури соціального працівника, зокрема - механізмів реалізації у ньому акмеологічного підходу $\epsilon$ актуальним завданням теорії сучасної професійної освіти.

Аналіз останніх досліджень і публікацій. Слід відзначити, що дослідження теоретичних засад, сутності, структури й технологій формування професійної та 
Журнал«Герспективита інновації науки

(Серія «Гедагогіка», Серія «Гтихологія», Серія «Медицина»

№4(4) 2021

методологічної культури представників різних професій (насамперед - вчителів) здійснено у працях О.Бережнової, Є.Бондаревської, Г.Валєєва, І.Зязюна, В.Краєвського, О.Лаврентьєвої, С.Сисоєвої, В.Сластеніна, та ін. Акмеологічний підхід як теоретична та методична основа організації процесу професійної підготовки майбутніх фахівців досліджено у працях О.Бодальова, А.Деркача, С.Вітвицької, О.Вознюка, О.Дубасенюк, В.Зазикіна, Н.Кузьміної та ін.. Проте теорія і практика реалізації акмеологічного підходу у процесі формування методологічної культури соціальних працівників залишаються практично недослідженими.

Мета статті - визначити теоретичні засади формування методологічної культури соціального працівника на основі акмеологічного підходу.

Виклад основного матеріалу. Враховуючи положення діяльнісного підходу доречно розглядати професійну діяльність сутністю буття людини (як суб'єкта) у професії. У цьому контексті, безумовно, процес розвитку методологічної культури слід інтерпретувати як складову процесу формування професіоналізму соціального працівника (як утворення, що, на нашу думку, найбільш повно характеризує інтеріоризацію особистістю системи професійно важливих знань, умінь, навичок, установок, традицій, цінностей, атрибутів тощо та пов'язаний з цим особистісний розвиток) й погодитись із методологами О.Анісімовим, В.Загвязінським, В.Краєвським, В.Полонським, котрі пов'язують формування методологічної культури фахівця 3 діяльнісно-конструктивним підходом до його професійної підготовки, самоосвіти і саморозвитку.

Зауважимо, що акмеологія («акме» - вершина, «логос» - наука) - напрям соціальних наук, що інтегрує знання про людину на етапі ії зрілості, що вивчає закономірності досягнення людиною «акме» (вершин) в різних видах життєдіяльності, в тому числі в освіті, самоосвіті і в професійній діяльності. Вперше термін “акмеологія” був введений до наукового обігу М.Рибніковим для позначення науки про розвиток дорослих (зрілих) людей. У тому ж значенні поняття «акмеологія» використовував Б.Ананьєв, який акцентував увагу на вивчення віку та фаз життя людини як індивіда та особистості. Акме ним визначалось як період активного розвитку та оволодіння повним комплексом соціальних та професійних функцій дорослої людини. Інший напрямок в розвитку акмеології започаткувала Н.Кузьміна, яка вивчала вплив здібностей дорослої людини на продуктивність та результативність професійної діяльності.

Слід відзначити, що категорія «професіоналізм» $є$ однією з базових у акмеологічних дослідженнях, у більшості науково-педагогічних досліджень 3 проблем теорії і методики професійної освіти розглядається як найбільш повна характеристика стану професійного розвитку майбутнього фахівця. Зокрема, у соціолого-педагогічному словнику за редакцією В.Радула професіоналізм педагога визначається як «сукупність психофізіологічних, психічних та особистісних змін, які відбуваються у людині в процесі оволодіння знаннями та довготривалої діяльності, що забезпечують якісно новий, вищий рівень 
розв'язання складних професійних завдань» [1, с. 203]. У короткому акмеологічному словнику А.Деркача та В.Зазикіна професіонал розглядається як суб'єкт професійної діяльності, який володіє високими показниками професіоналізму особистості та діяльності, само ефективності; такий, що має високий професійний і соціальний статус, систему особистісної та діяльнісної нормативної регуляції, що динамічно розвивається; є постійно спрямованим на саморозвиток та самовдосконалення, що мають соціально-позитивне значення [2, c. 227]. За визначенням О.Бодальова, «професіонал - це суб'єкт діяльності, який володіє такими характеристиками розуму, волі, почуттів, або, такими психічними властивостями, які складають сталу структуру, дозволяють йому на високому рівні продуктивності виконувати ту діяльність, якою він зарекомендував себе як хороший фахівець.» Учений зазначає, що «...дійсний професіоналізм завжди пов'язаний із сильною мотиваційно-емоційною зарядженістю на здійснення саме цієї діяльності і на досягнення в ній унікального, неординарного результату» [3, с.74].

Акмеологічна концепція Е.Зеєра дозволяє говорити про «життєвий шлях» професіонала, що включає п'ять стадій професіоналізації:

1. Оптацію - вибір професії з урахуванням індивідуально-особистісних i ситуативних особливостей.

2. Професійну підготовку - здобуття професійних знань, умінь і навичок.

3. Професійну адаптацію - входження в професію, освоєння соціальної ролі, професійне самовизначення, формування якостей і досвіду.

4. Професіоналізацію - формування професійної та соціальної позиції, інтеграція особистісних і професійних якостей у процесі виконання професійних обов'язків.

5. Професійну майстерність - реалізацію особистості в професійній діяльності [4].

Ми враховуємо думку В.Сластеніна, що слід розрізняти професіоналізм діяльності та професіоналізм особистості. Учений вважає що спочатку було розуміння професіоналізму як характеристики діяльності людини. Проте згодом, 3 розумінням того, що професійні досягнення можуть зумовлюватися не лише організацією праці та професійною підготовкою, але й розвитком особистісних якостей i характеристик, дослідники усвідомили необхідність цілісного тлумачення феномену професіоналізму у діяльнісному та особистісному проявах [5].

Отже, професіоналізм діяльності - це здатність майбутнього соціального працівника стабільно демонструвати високі зразки професійної діяльності відповідно до сучасної філософії освіти та парадигми педагогічної діяльності, у процесі виконання функціональних обов'язків згідно посадових вимог.

3 сучасних акмеологічний позицій, професіоналізм діяльності - якісна характеристика суб'єкта праці, що відображає високу професійну кваліфікацію і компетентність, різноманітність ефективних професійних умінь i навичок, 
Журнал«Герспективитаінновації науки»

(Серія«Гедагогіка», Серія«Гцихологія», Серія«Медицинв»

№4(4) 2021

зокрема таких, що засновані на творчих рішеннях, володіння сучасними алгоритмами і способами розв'язання професійних задач, що дозволяє здійснювати діяльність 3 високою і стабільною продуктивністю.

За визначенням А.Деркача, професіоналізм особистості - якісна характеристика суб'єкта праці, що відображає високий рівень розвитку професійно важливих і особистісно-ділових, акмеологічний інваріантів професіоналізму, високий рівень креативності, адекватний рівень домагань, мотиваційну сферу і ціннісні орієнтації, спрямовані на прогресивний розвиток фахівця [2].

Ми враховуємо думку Є.Клімова, що професіоналізм - це особливий психологічний стан особистості, що характеризує не тільки вищий рівень знань $і$ результати людини в певній сфері діяльності, але й певну системну організацію свідомості, психіки людини [6]. Тобто в поняття «професіоналізм» Є. Клімов уводить не просто знання, уміння й навички, важливим чинником $\epsilon$ i розвиток особистості професіонала, що містить, як мінімум, наступні компоненти:

1. Особистісні характеристики суб'єкта діяльності: образ світу; спрямованість, соціально орієнтовані мотиви; ставлення до зовнішнього світу, до людей, до діяльності; ставлення до себе, особливості саморегуляції; креативність, іiі здібності; інтелектуальні риси; особливості індивідуальності; емоційність, іiі особливості й вияви; особливості усвідомлення спорідненості своєї професії 3 іншими; уявлення про педагогічні здібності, поєднання особистісних якостей, і необхідних для професіонала; уявлення про своє місце в професійній спільноті.

2. Діяльнісні характеристики професіонала (особливості здійснення практичної діяльності): моторика; уміння, навички, орієнтовані на предметну сферу праці; комунікативні вміння й навички, уміння здійснювати соціальний вплив; уміння й навички саморегуляції.

3. Особливості знань професіонала: сприйняття інформації, увага, професійна специфіка уваги, відчуття і сприйняття; переробка інформації й ухвалення рішень, пам’ять, мислення, уява, їх професійна специфіка; здатність поновлювати знання відповідно до науково-технічного прогресу, прагнення до вдосконалення професійних знань.

4. Інформованість, досвід і культуру професіонала.

5. Психодинаміку, інтенсивність і швидкість зміни переживань.

Слід відзначити, що існує декілька підходів щодо визначення змісту методологічної культури. Представники першої, опираючись на праці В.Краєвського, розглядають зміст методологічної культури переважно через методологічну рефлексію (як уміння аналізувати власну наукову та практичну діяльність), а також - здатність (вміння і здібності) до наукового узагальнення, критичного аналізу й творчого застосування певних концепцій, форм i методів пізнання, управління, конструювання педагогічного процесу [7, с.11]. Інша група науковців намагається розширити зміст методологічної культури, вводячи до 
нього аксіологічний компонент, систему мотивації. Зокрема, В.Сластенін вважає, що крім знань та вмінь, до методологічної культури слід віднести наступні позиції:

1. Перетворення педагогічної теорії в метод пізнавальної діяльності.

2. Намагання виявити єдність та спадкоємність психолого-педагогічних знань в процесі їх історичного розвитку.

3. Критичне ставлення до положень, аргументів, які знаходяться у площині педагогічної свідомості.

4. Рефлексія передумов, процесу i результатів власної пізнавальної діяльності, а також думок інших учасників процесу навчання та виховання.

5. Доказові спростування антинаукових позицій в галузі людинознавства.

6. Розуміння і прийняття світоглядних та гуманістичних функцій педагогіки та психологіï [8].

Таким чином, зміст і структура методологічної культури можуть бути представлені як певна емпірична реальність, як образ, що безпосередньо постає перед соціальним працівником у його „внутрішньому досвіді” і скеровує його практичну діяльність.

Крім того, методологічну культуру слід розглядати з позицій системного підходу, як цілісну, складноієрархічну систему у професійній структурі особистості, що складається і функціонує у взаємодії: об'єктивної (мобікультурні об'єкти та реалії) та суб'єктивної (відбиток культури у свідомості) iї форм, раціональної та емоціонально-чуттєвої ії складових, культурно-іноваційних механізмів та властивих культурі способів забезпечення самоідентифікації.

Спираючись на вищенаведені наукові джерела, а також праці $\mathrm{C}$. Бондаревської, В.Краєвського, О.Лаврентьєвої методологічну культуру ми розглядаємо як цілісне багаторівневе і багатокомпонентне утворення у структурі особистості соціального працівника, що містить знання фахової методології, володіння методами і методологією наукового пізнання, розумову діяльність в режимі методологічної рефлексії, розвинуті здібності критичного аналізу професійної діяльності, систему інтеріоризованих педагогічних та загальнолюдських цінностей, котрі визначають професійну свідомість.

В межах акмеологічного підходу існує розуміння методологічної культури як певного феномену, що багатовимірно характеризує стан особистості, $\epsilon$ умовою досягнення ним найвищих показників в особистісно-соціальному розвитку, професійній діяльності, творчості. Зокрема, О. Ходусов методологічну культуру представляє як образ ідеального професійного буття вчителя, що включає онтолого-гносеологічну й методологічну інтерпретацію його професійної діяльності. Цей образ відображує внутрішній духовний стан i надбання вчителя. Завдяки цьому створюється концепція, стратегія професійного мислення, поведінки й діяльності [9].

Оскільки наявність у соціального працівника засобів саморозвитку пов'язана 3 адекватним теоретичним розумінням організованості його 
самосвідомості, визначеного на основі категорії культуростворюючої дії (В.Зінченко, В.Кудрявцев, В.Лазарєв та ін.), слід, на нашу думку, розглядати професійний розвиток у контексті культурно-значеннєвої реальності, тобто - як обумовлене взаємодією простору професійної діяльності і соціокультурного простору.

Ми враховуємо думку П.Кабанова, що методологічна культура - це механізм, який зберігає людину в даному смисловому полі. Без методологічної культури людина випадає з цього смислового поля із-за різних перешкод, що виникають в ході іiі діяльності. Звідси не всі методологічні установки потрапляють в розряд культурних, а тільки ті, які показали свою ефективність у практиці їх застосування, яким віддається перевага [10, с.15-17].

Враховуючи характер виникаючих у процесі праці справжнього професіонала пікових (А.Маслоу) та трансцендентних (А.Чиксентміхайї) переживань, досягнення “акме” - це напруження всіх сил. Таке відбувається, коли в модусі життєвих цілей, у світоглядно-спрямовуючій функції методологічної культури закріплюється вимога обов'язкового досягнення поставлених життєвих цілей. Відповідно, коли сенсом діяльності стає реалізація комплексу життєвих і професійних цілей, закріплених у професійній культурі, “акме” стимулює накопичення, збільшення актуальних можливостей особистості, ii творчу діяльність, свободу і відповідальність, тобто самореалізацію в професії.

Цінності можуть проявлятися як значення, як мета і як принцип поведінки. В останньому випадку ціннісні орієнтації, що досягають значення принципу, дозволяють досягти згоди в соціальній групі. Цінність як норма дозволяє посилити впорядкованість взаємодії у субкультурі чи професійній групі, чітко визначити виконання відпрацьованих правил.

Відтак необхідною умовою формування методологічної культури соціальних працівників $є$ врахування принципів педагогічної аксіології та акмеології, (С.Анісімов, О.Деркач, О.Здравомислов, М.Каган, В.Розанов, В.Тугаринов) у процесі їхньої соціалізації та професійної підготовки.

Враховуючи положення культурологічного підходу до професійної освіти майбутніх соціальних працівників ми можемо припустити, що методологічна культура у об'єктивному вимірі існує як певний символічний простір. У процесі діяльності (навчальної, наукової, самоосвітньої, громадської) майбутні соціальні педагоги залучаються до зразків методологічної культури, зафіксованих у соціокультурному просторі (субкультурі) ВН3, сприймають вже генеровані ідеї, народжують нові. Під час діяльності суб’єктів цього процесу зразки методологічної культури транслюються, зберігаються, сприймаються i використовуються як об'єктивні і суб'єктивні явища. Суб'єктивними ці явища стають тому, що хтось (певний суб'єкт) є автором тієї чи іншої ідеї, що становить основу явища, а об'єктивними - тому що ці явища відкриваються іншими суб'єктами, для яких вони існують об'єктивно, оскільки є результатом діяльності 
інших дослідників і визнаються науковим загалом.

Ми погоджуємось з О.Ходусовим [9], що однією з провідних характеристик методологічної культури соціального працівника $\epsilon$ спрямованість (система цінностей), що представлена у вигляді блоку цілей i його критеріїв. Серед останніх слід виділити такі критерії: усвідомленість цінностей і відношення до них; дії по вибору цінностей; реалізація їх як особистісних цілей діяльності.

Соціальна робота являється одним із способів реагування суспільства на нову соціальну ситуацію, iii проблеми, можливості. Крім того, це один 3 найважливіших інструментів соціального контролю. Тому важливою акмеологічною характеристикою методологічної культури соціального працівника є сформованість у нього професійної та соціальної позиції.

В. Сластенін підкреслює, що передумовами для формування професійної позиції може стати знайомство з проблемами діяльності, а також, що саме в позиції соціальний працівник здатен виражати свій інтелект, емоції, почуття, волю, професійні переконання, темперамент, характер і формувати на цій основі систему ставлень до фахової діяльності й професійного оточення. Вважаємо, що професійна позиція соціального працівника має різні контексти: особистісний, який виявляється в роботі фахівця 3 клієнтами й виражається в професійних діях, зумовлених індивідуальним ставленням до кожної конкретної людини; професійний, що зумовлює вираження соціальним працівником через позицію свого культурного розвитку, цілей діяльності, прагнень здійснювати результативну роботу, розвиватись як творча особистість [5].

Вважаємо, що розвиток професійної позиції забезпечує ефективність роботи соціального працівника; дозволяє формувати у них широкий світогляд, систему культурних і суспільних цінностей на основі власного життєвого досвіду; забезпечує результативність форм, методів і засобів впливу, які застосовуються соціальним працівником під час роботи 3 клієнтами; сприяє формуванню людини як особистості. Професійна позиція виражає готовність соціального працівника до виконання свого професійного призначення відповідно до вимог $\mathrm{i}$ запитів суспільства й визначається усвідомленим, відповідальним ставленням його до діяльності та до себе як суб'єкта діяльності.

Розкриття творчого потенціалу, креативності особистості, творча самореалізація в професійній діяльності також є важливою умовою становлення ii професіоналізму. Методів розвитку креативності особистості існує чимало: одні з них пов'язані з підвищенням культури рефлексії, інші - iз стимулюванням особливого психічного стану творчої активності - натхнення, треті - iз застосуванням методів активізації пошуку ідей, четверті - 3 розвитком здібностей, п'яті - 3 пошуком внутрішніх спонукальних причин активізації творчої активності. Важливо відзначити, що всі вони сприяють творчій самореалізації і зростанню професіоналізму особистості соціального працівника $\mathrm{i}$ можуть без обмеження застосовуватися на практиці.

Креативність, безумовно, $\epsilon$ необхідною умовою формування професіонала, 
але в той же час ця якість особистості повинна мати цілком певну спрямованість, пов'язану із специфікою професійної діяльності. Акмеологи дану спрямованість називають інноваційною [2]. Дійсно, досягнення професіоналізму немислиме без новаторського підходу, який може виявлятися в освоєнні нових ефективних алгоритмів і способів виконання діяльності, в нетривіальному вирішенні професійних задач. Тільки спрямованість на творення дозволить отримати якісно інші результати, здійснювати прорив в нові області професійної діяльності. Відсутність інноваційної спрямованості може принести до того, що сам суб'єкт праці зупиниться на рівні професійної майстерності (хоч і цей рівень з огляду суспільної потреби якості праці є бажаним). Розвиток інноваційного потенціалу і спрямованості особистості може здійснюватися в першу чергу шляхом вибору відповідних еталонів і відповідності їм.

Слід наголосити, що суб'єкт праці прагне до особистісно-професійного розвитку і досягнення високого рівня професіоналізму у тому випадку, коли у нього сильні, але адекватні мотиви професійних досягнень і професійної самореалізації. На думку одного із засновників гуманістичної психології К.Роджерса, поведінка i діяльність людини завжди регулюється певним об'єднуючим мотивом - потребою актуалізації.

Мотиви діяльності майбутнього соціального працівника можуть бути усвідомленими і неусвідомлюваними i, на нашу думку насамперед пов'язані 3 пізнавальними процесами, а також - 3 потребою одержати професію і відповідну кваліфікацію. Сукупність таких інтеріоризованих мотивів утворюють мотивацію особистості соціального працівника як систему чинників, що спонукають до відповідної активності, до дії або бездіяльності в певних ситуаціях.

Ознаками зрілої мотиваційної сфери, як показника сформованості акме соціального працівника, на нашу думку, $є$ :

-множинність та розмаїтість спонукань, наявність у світогляді таких спонукань як мета, мотиви, інтереси тощо, що зміцнюють мотивацію в різних умовах професійної діяльності;

•якість і наявність необхідних параметрів кожного з спонукань;

- ієрархічність, виокремлення провідних спонукань;

•перевага конструктивної спрямованості мотиваційної сфери;

•гнучкість, схильність до змін залежно від умов праці, соціальних відносин у суспільстві, соціокультурному середовищі тощо.

В результаті проведених досліджень було встановлено, що процес формування методологічної культури майбутнього соціального працівника буде ефективним за умов:

- методологізації професійної підготовки соціального працівника, що обумовлює посилення та концептуалізацію професійної підготовки, логізацію змісту професійної освіти, приведення іiі складових у відповідність до змісту професійної діяльності, виокремлення методологічних зв'язків на міждисциплінарній основі, підвищення пізнавальної самостійності, культури 
розумової праці, активності у здобуванні і використанні знань, формування, проектувально-технологічних та методологічних знань та вмінь, ціннісного ставлення до професійних знань та процесу їх здобуття;

- ініціювання у соціального працівника професійної рефлексії через моделювання у навчальному процесі елементів майбутньої професійної діяльності, інтенсифікацію практичного компоненту навчання, самостійної та сомоосвітньої навчальної діяльності, ознайомлення з методиками професійного самовдосконалення;

- активізації науково-дослідної роботи майбутнього соціального працівника, спрямованої на наукове осмислення закономірностей соціально-педагогічного процесу, розвиток компетенції методологічного аналізу наукової літератури, умінь і навичок самостійної організації науково-дослідної діяльності;

- розвитку соціокультурного середовища університету на засадах національної та професійної культури, творчої реалізації в організації освітнього процесу професійно орієнтованих технологій i методик, спрямованих на розвиток інтересу особистості до професійної діяльності, формування власної професійної позиції, професійної „Я-концепції,, індивідуальних здібностей, якостей і характеристик.

До провідних акмеологічних механізмів формування методологічної культури соціального працівника, на нашу думку, слід віднести:

- адаптацію у професійному середовищі з компенсаторним ефектом;

- ідентифікацію сенсу й стратегії життя з професійним ідеалом;

- спонукання внутрішньої активності соціального працівника в його взаємодії з соціокультурним середовищем.

Важливою умовою формування методологічної культури майбутнього соціального працівника $\epsilon$, на нашу думку, врахування у процесі професійної підготовки основних акмеологічних законів, якими за А.Деркачем і В.Зазикіним є:

1) закон особистісно-професійного розвитку i примноження особистісного потенціалу встановлює взаємозв'язок між процесом становлення професійних характеристик і формуванням цілісної особистості;

2) закон самовираження особистості в професії, який описує процеси i механізми професійного самовизначення, самоствердження, самореалізації, створення професійного образу «Я» $\mathrm{i}$ особистісно-професійного росту в контексті самовираження особистості в професії [2, с.51-52].

Висновки. Отже, не претендуючи на повноту й вичерпність висвітлення даної проблеми в межах цієї статті, вважаємо, що методологічна культура $є$ важливим компонентом професіоналізму соціального працівника, визначає адекватність сприйняття ним професійної дійсності, спроможність до організації творчої професійної діяльності на наукових засадах, здатність до самоаналізу й самоактуалізації, можливість досягнення вершин у професійній діяльності, активно формується у процесі цілісної взаємодії студента 3 соціокультурним простором вищого навчального закладу. Важливою умовою ефективного 
Журнал«Герспективитаінноваціїнауки

(Серія «Педагогіка», Серія«ГЕихологія», Серія«Медицина»

№4(4) 2021

становлення методологічної культури майбутнього соціального працівника $\epsilon$ реалізація у процесі професійної підготовки наукових засад та принципів педагогічної акмеології.

\section{Лimepamypa:}

1. Соціолого-педагогічний словник / За ред. В.В.Радула. Київ: “Екс.Об”, 2004. 304 с.

2. Деркач А.А. Акмеология: Учебное пособие. Санкт-Петербург: Питер, 2001. 256 с.

3. Бодалев А.А. Вершина в развитии взрослого человека: характеристики и условия достижения. - Москва: Флинт-Наука, 1998. 230 с.

4. Фирсов М.В. Теория социальной работы: Учебное пособие. Москва: ВЛАДОС, 2001. $432 \mathrm{c}$.

5. Сластенин В.А. Рефлексивная культура и профессионализм учителя. Педагогическое образование и наука. 2005. № 3. С.37-43.

6. Климов Е.А. Психология профессионала. Москва: Изд-во «Институт практической психологии», Воронеж: НПО «МОДЭК», 1996. 400 с.

7. Краевский В.В. Методология педагогики: Пособие для педагогов-исследователей. Чебоксары: Изд-во Чувашского, ун-та, 2001. 244 с.

8. Сластенин В.А. Формирование профессиональной культуры учителя. Москва: Прометей, 1993, 178 с.

9. Ходусов А.Н. Методологическая культура как условие совершенствования и обогащения профессиональной подготовки учителя. Социально-nсихологические аспекть оптимизации жизнедеятельности молодёжных групп в изменяющихся сощииальноэкономических условиях: сб. научн. трудов памяти проф. Л. И. Умайского. - Курск: КГПУ, 2000. 339c.

10. Кабанов П.Г. Вопросы совершенствования методологической культуры педагога. Томск: Изд-во ТГУ, 1999. 140 с.

\section{References:}

1. Radula, V.V. (2004). Sociologo-pedagogichnij slovnik [Social-pedagogical vocabulary]. Kiïv: "Eks.Ob" [in Ukrainian].

2. Derkach, A.A. (2001). Akmeologija [Acmeology]. Sankt-Peterburg: Piter [in Russian].

3. Bodalev, A.A. (1998). Vershina v razvitii vzroslogo cheloveka: harakteristiki i uslovija dostizhenija [The pinnacle in the development of an adult: characteristics and conditions for achievement]. Moskva: Flint-Nauka [in Russian].

4. Firsov, M.V. (2001). Teorija social'noj raboty [Social Work Theory]. Moskva: VLADOS [in Russian].

5. Slastenin, V.A. (2005). Refleksivnaja kul'tura i professionalizm uchitelja [Reflective culture and teacher professionalism]. Pedagogicheskoe obrazovanie i nauka - Pedagogical education and science, 3, S.37-43 [in Ukrainian].

6. Klimov, E.A. (1996). Psihologija professional [Psychology of a professional]. Moskva: Izd-vo «Institut prakticheskoj psihologii», Voronezh: NPO «MODJeK» [in Russian].

7. Kraevskij, V.V. (2001). Metodologija pedagogiki [Methodology of Pedagogy]. Cheboksary: Izd-vo Chuvashskogo, un-ta [in Russian].

8. Slastenin, V.A. (1993). Formirovanie professional'noj kul'tury uchitelja [Formation of the teacher's professional culture]. Moskva: Prometej [in Russian].

9. Hodusov, A.N. (2000). Metodologicheskaja kul'tura kak uslovie sovershenstvovanija $i$ obogashhenija professional'noj podgotovki uchitelja. Social'no-psihologicheskie aspekty optimizacii 
zhiznedejatel'nosti molodjozhnyh grupp v izmenjajushhihsja social'no-jekonomicheskih uslovijah: sb. nauchn. trudov pamjati prof. L. I. Umajskogo [Methodological culture as a condition for improving and enriching the professional training of a teacher. Socio-psychological aspects of optimizing the life of youth groups in changing socio-economic conditions: collection of articles. scientific. works in memory of prof. L. I. Umaysky]. - Kursk: KGPU [in Russian].

10. Kabanov, P.G. (1999). Voprosy sovershenstvovanija metodologicheskoj kul'tury pedagoga [Questions of improving the methodological culture of the teacher]. Tomsk: Izd-vo TGU [in Russian]. 